Original Article

\title{
EVALUATION OF DIFFERENT CULTURE MEDIA FOR ENHANCED PRODUCTION OF PSEUDOMONAS AERUGINOSA (MTCC NO 2453) BIOMASS AND ITS PROTEINS
}

\author{
P. NEERAJA ${ }^{\mathrm{a}^{*}}$, T. PARTHASARATHY ${ }^{\mathrm{b}}$, M. SUDHAKAR ${ }^{\mathrm{c}}$ \\ Department of Pharmacy, University College of Technology, Osmania University, Hyderabad, Telangana 500007, India, Department of \\ Chemistry, Osmania University, Hyderabad, Telangana 500007, India, Department of pharmaceutics, Malla Reddy College of Pharmacy, \\ Maisammaguda, Secunderabad, Telangana 500014, India \\ Email: neerajapodichety@gmail.com \\ Received: 01 Jul 2016 Revised and Accepted: 09 Sep 2016
}

\begin{abstract}
Objective: Microorganisms, especially bacteria and its proteins have proven to be potential anti-cancer agents as they selectively attack the tumor cells or tumor micro-environments. The extract of Pseudomonas aeruginosa found to contain proteins that have shown promising anticancer activity. In this work, it was attempted to increase the biomass and trigger the total protein fraction of Pseudomonas aeruginosa (MTCC 2453).

Methods: The organism was cultivated in three different such as Luria-Bertani (LB) broth, minimal medium9 (M9), super broth medium (SB) and asparagine-proline (AP) broth. Asparagine proline broth was selected as it has shown high cell growth rate. The media was further optimized by the addition of $\mathrm{NaHCO}_{3}$ and copper sulphate to trigger the protein production. Optimized Aspergine proline broth has achieved highest cell biomass. After the shake flask culture, the overnight grown culture in optimized AP medium was further grown in a $5 \mathrm{~L}$ bioreactor by fed-batch cultivation to achieve higher cell densities.
\end{abstract}

Results: The highest protein production was achieved at $40^{\circ} \mathrm{C}$. Highest biomass and protein content was observed at pH 8 while lowest biomass was produced at $\mathrm{pH} 2$. A gradual increase in biomass content observed from $12 \mathrm{~h}$ towards to $48 \mathrm{~h}$.

Conclusion: High biomass and proteins content and of Pseudomonas aeruginosa (MTCC 2453) can be produced in optimized asparagine-proline broth. Further the extract is purified to produce novel anti-cancer proteins.

Keywords: Pseudomonas aeruginosa, Anticancer activity, Bacterial proteins, Optimized media, Biomass and asparagine-proline broth

(C) 2016 The Authors. Published by Innovare Academic Sciences Pvt Ltd. This is an open access article under the CC BY license (http://creativecommons. org/licenses/by/4. 0/) DOI: http://dx.doi.org/10.22159/ijpps.2016v8i11.13809

\section{INTRODUCTION}

Today, cancer treatment is facing difficulties with secondary effects caused by standard therapies and affected by tumor cell resistance. There is no effective drug or vaccine exists to prevent cancer initiation, drug resistance and toxicity. Bacterial proteins are studied as one of the potential strategies to treat cancer.

Live, attenuated bacteria have shown the ability to act as anticancer agents [1]. But sometimes they may cause infections and cross contamination reactions. Bacterial proteins have been extensively studied as anticancer agents [2]. These proteins found to act on tumor cells specifically and cause tumor regression through growth inhibition; cell cycle arrest and apoptosis induction [3]. Protein from Pseudomonas aeruginosa, Streptococcus pneumoniae, Corynebacterium diphtheria and enterococcus sp. has exhibited prominent anti-cancer activity against human cell lines [4]. Bacillus thuringiensis found to contain a new anticancer protein [5].

Clostridium novyi demonstrated significant anti-tumor effects. $C$. novyi has also been investigated in conjunction with radiotherapy, radioimmunotherapy, and further chemotherapy in experimental tumor models. Protein such as Pseudomonas exotoxin, diphtheria toxin, and ricin may be useful in cancer therapy $[8,9]$.

The crude extract derived from Pseudomonas sp. isolated from soil in Greenland has shown promising antimicrobial and anticancer properties [10].

The extract of Pseudomonas aeruginosa found to contain proteins such as azurin that have shown promising anticancer activity. The cell growth and protein production by Pseudomonas is influenced by carbon, nitrogen sources and growth factors.

Pseudomonas aeruginosa contains largest genomes. This bacterium adapts to diverse ecological environments, ranging from water and soil to human bodies. P. aeruginosa possesses more complicated metabolic and protein sorting pathways than Gram-negative bacteria with smaller genome sizes. It contains genes involved in the expression of various proteins especially redox type which can act as prominent anti-cancer agents [11]. Unlike anticancer drugs that target a specific step in the cancer progression pathway, bacterial proteins target multiple steps in the cancer progression pathways, thereby interfering in cancer growth both in vitro and in vivo. Hence, in this work an effort was made to increase the biomass and total protein content of Pseudomonas aeruginosa extract by using different culture media and growth conditions.

\section{MATERIALS AND METHODS}

\section{Materials}

Bacterial strains (Pseudomonas aeruginosa MTCC 2453 collected from Microbial Type Culture Collection, Chandigarh, India), Components of culture medium for the cultivation of bacterial strains such as yeast extracts, peptone, potassium phosphate, sodium hydrogen phosphate, copper sulfate, potassium nitrate, sodium dodecyl sulfate, etc. Luria-Bertani (LB) broth, minimal medium9 (M9), super broth medium (SB), and asparagine-proline (AP) broth are used for the study.

\section{Optimization of media}

Pseudomonas aeruginosa (MTCC 2453) collected from MTCC, Chandigarh, India and cultivated in three different types of media. The media such as Luria-Bertani (LB) broth, minimal medium9 (M9), super broth medium (SB) and asparagine-proline (AP) broth were used for the study.

\section{Preparation of inoculum and shake flask culture}

The organisms were inoculated in $50 \mathrm{ml}$ of LB medium in $250 \mathrm{ml}$ Erlenmeyer flasks to prepare seed culture. It was incubated $37^{\circ} \mathrm{C}$ for 
$24 \mathrm{~h}$ in an orbital shaker incubator at $100 \mathrm{rpm}$. Two $\mathrm{ml}$ of the seed culture is added to $200 \mathrm{ml}$ of the selected culture media in a $1 \mathrm{~L}$ Erlenmeyer flask and incubated at $37{ }^{\circ} \mathrm{C}, 200 \mathrm{rpm}$ for $10 \mathrm{~h}$ to prepare to shake flask culture. 0.5 mmol IPTG was added after $\sim 4 \mathrm{~h}$ (when cultures were in the logarithmic growth phase), and further grown for $4 \mathrm{~h}$. The media used were listed in table 1 . After the incubation time, dry cell weight is measured. The Lowry method is used for total protein estimation. The color density was recorded using spectrophotometer at $660 \mathrm{~nm}$ and compared to a standard curve of protein (BSA $1 \mathrm{mg} / \mathrm{ml}$ ).

\section{Optimization of culture conditions}

Varying culture parameters were studied to increase the yield of total protein fraction in optimized media (Asparagine proline broth) such as the effect of temperature, $\mathrm{pH}$, and incubation time. Influences of these parameters were used to determine the total biomass and total protein fraction at $6600 \mathrm{~nm}$. Uninoculated medium served as media control $[12,13]$.

\section{Effect of temperature}

The effect of temperature on protein production was determined at varying temperatures viz. $30,35,40$ and $45^{\circ} \mathrm{C}$ maintained during the incubation period of inoculums used for protein production. To 100 ml production medium (pH: 7) 1\% inoculum was added and incubated for 24-48h.

\section{Effect of pH}

Effect of $\mathrm{pH}$ on protein production by the bacterial cultures was determined at optimized temperature for 24-48 $\mathrm{h}$ while varying the $\mathrm{pH}$ values of the medium viz. 2, 4, 6, 8 and 10 .

\section{Effect of incubation period}

Effect of incubation time was evaluated at optimized temperature and $\mathrm{pH}$. Production flasks were subjected to different incubation time viz. $0,12,24,48,72$ and $96 \mathrm{~h}$.

\section{Determination of biomass by cell dry weight}

The cells from inoculated flasks, each containing $50 \mathrm{ml}$ were centrifuged using a cooling centrifuge (Cooling Microcentrifuge Model C-24BL, Remi) in pre-weighted centrifugation tubes of $50 \mathrm{ml}$ volume at $6000 \mathrm{rpm}$ for $10 \mathrm{~min}$. The cell precipitates were collected, washed with sterile $0.9 \%$ saline solution and re-centrifuged. The supernatants were discarded, and the centrifugation tubes were dried in an oven (Hot air oven BTI-29, Biotechnics, India) at $100{ }^{\circ} \mathrm{C}$ till constant weights were obtained. The weight of the dried cells was measured by calculation of the difference between the weight of centrifugation tubes before and after dryness.

\section{Cell disruption by ultrasonication and total protein estimation}

$2 \mathrm{ml}$ of bacterial culture was taken in five eppendorf tubes and centrifuged at $10000 \mathrm{rpm}$ for $5 \mathrm{~min}$ and the cell pellets is were kept in ultrasonic wave generator After sonication, the eppendorf tubes were centrifuged at $10000 \mathrm{rpm}$ for $5 \mathrm{~min}$. Supernatant is taken, and the amount of protein in the sample is determined by Lowry's method.

\section{Optimized broth for cultivation of Pseudomonas aeruginosa strains}

Cultivation of bacterial strains is done using enrichment method. Asparagine proline broth is selected for the cultivation of selected Pseudomonas aeruginosa strains. It contains DL-asparagine $2 \mathrm{~g} / \mathrm{l}, \mathrm{L}$ proline $1 \mathrm{~g} / \mathrm{l}$, dipotassium phosphate, anhydrous $1 \mathrm{~g} / \mathrm{l}$, magnesium sulfate $0.5 \mathrm{~g} / \mathrm{l}$ and potassium sulfate $10 \mathrm{~g} / \mathrm{l}$. To increase the yield of protein, the medium was optimized by addition of $0.05 \% \mathrm{NaHCO}_{3}$, copper sulphate $0.01 \%$ yeast extract, succinate, methylamine, and methanol.

\section{Statistical analysis}

Data analysis was done using SPSS software version 10 for windows. The results were represented as mean \pm SE for three replicates.

\section{Fed-batch cultivation Pseudomonas aeruginosa strains}

After the shake flask culture, the overnight grown culture in optimized asparagine-proline broth medium was further grown in a $3 \mathrm{~L}$ bioreactor by fed-batch cultivation to achieve higher cell densities. After approximately $18 \mathrm{~h}$ of bioreactor cultivation $(\sim 4$ after induction), final biomass yield was measured. The bioreactor provides for control of culture $\mathrm{pH}$, effective aeration, feeding with a carbon source, antifoam, and a nitrogen source, and also maintains culture sterility.

\section{RESULTS}

In shake flask culture, final cell concentration was found to depend on upon the media used. Cell biomass was measured and reported in table 2. Asparagine proline broth was selected as it has shown high cell growth rate. The media was further optimized by the addition of $\mathrm{NaHCO}_{3}$ and copper sulfate to trigger the protein production. Optimized asparagine-proline broth has achieved highest cell biomass. Influences of various culture conditions such as temperature, Ph, Incubation time on the cultivation of Pseudomonas aeruginosa in optimized asparagine-proline broth were studied to determine the total biomass and total protein fraction at $660 \mathrm{~nm}[14]$.

The findings were reported table 3,4 , and 5 . The highest protein production was achieved at $40{ }^{\circ} \mathrm{C}$. Highest biomass and protein content was observed at $\mathrm{pH} 8$ while lowest biomass was produced at $\mathrm{pH}$ 2. A gradual increase in biomass content observed from $12 \mathrm{~h}$ towards to $48 \mathrm{~h}$. After $48 \mathrm{~h}$ of incubation time, a decrease in the biomass was observed. Overall the highest biomass was observed when the organism grown in asparagine-proline broth at $40{ }^{\circ} \mathrm{C}$ at a slightly alkaline pH of 8 for a period of $24 \mathrm{~h}$. There was an increase in yield of the biomass almost two when culture grown in a fedbatch bioreactor for a period of $24 \mathrm{~h}$.

Table 1: Composition of different media used for cultivation of Pseudomonas aeruginosa (MTCC 2453) (g/l)

\begin{tabular}{lll}
\hline S. No. & Media & Composition (g/l) \\
\hline 1 & LB & Tryptone,10.0 g; Yeast extract, 5.0 g; NaCl, 5.0 g; \\
2 & SB & Soy Hydrolysate, 12.0 g, Yeast Extract, 24.0 g; Di-potassium phosphate, 11.4 g; Monopotassium phosphate, 1.7 g; Glycerol, 5 g; \\
3 & M9 & Di-sodium phosphate, 6.78 g; Sodium Chloride, 0.5 g; Ammonium chloride, 1.0 g; Mono potassium phosphate, 3.0 g; \\
4 & AP & DL-Asparagine, 2 g; L-Proline, 1 g; Di potassium phosphate, anhydrous 1 g; Magnesium sulfate, 0.5 g and Potassium sulfate 10 g; \\
5 & Optimized & DL-Asparagine, 2g; L-Proline, 1 g; Di potassium phosphate, anhydrous,1g; Magnesium sulfate, 0.5 g; Potassium sulfate,10 g; \\
& media & $0.05 \%$ NaHC03, copper sulfate 0.01\% yeast extract, succinate, methylamine and methanol. \\
\hline
\end{tabular}

Table 2: Dry cell weight of Pseudomonas strains in different media

\begin{tabular}{lll}
\hline S. No. & Media & Dry cell weight(g/l) of Pseudomonas aeruginosa (MTCC2453) \\
\hline $\mathbf{1}$ & LB & 1.15 \\
$\mathbf{2}$ & M9 & 1.18 \\
$\mathbf{3}$ & SB & 1.95 \\
$\mathbf{5}$ & AP & 2.82 \\
$\mathbf{6}$ & Optimized media & 4.34 \\
$\mathbf{7}$ & Optimized media(Fed batch) & 7.25 \\
\hline
\end{tabular}




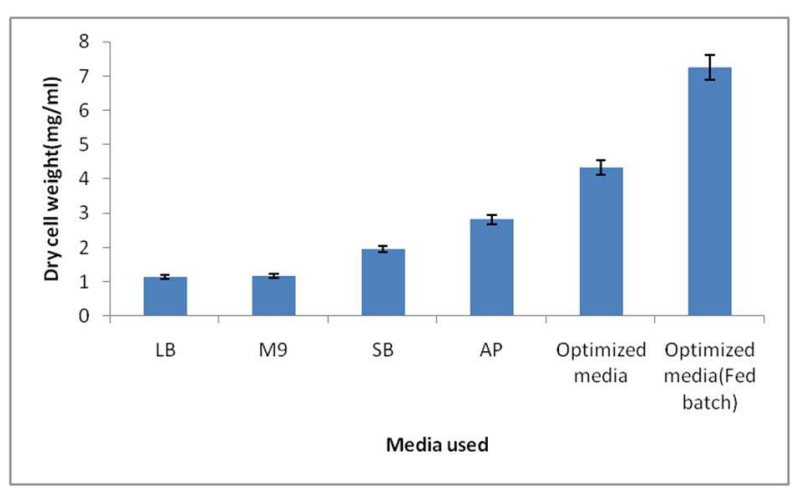

Fig. 1: Effect of different media on dry cell weight of Pseudomonas aeruginosa (MTCC 2453). To determine the dry cell weight, $50 \mathrm{ml}$ of shake flask culture of the organism in different culture media was collected and centrifuged and dried. Media represented on $x$-axis and dry cell weight for three replicates was taken on $y$-axis $(n=3)$

Table 3: Effect of $\mathrm{pH}$ on biomass and total protein fraction of Pseudomonas aeruginosa (MTCC 2453)

\begin{tabular}{lll}
\hline S. No. & $\mathbf{p H}$ & Total protein content $(\mathbf{m g} / \mathbf{m l})$ \\
\hline 1 & 2 & $0.87 \pm 0.01$ \\
2 & 4 & $1.42 \pm 0.04$ \\
3 & 6 & $1.63 \pm 0.03$ \\
4 & 8 & $2.55 \pm 0.03$ \\
5 & 10 & $2.01 \pm 0.04$ \\
\hline
\end{tabular}

Data represent as mean \pm standard error (SE) for three replicates $(n=3)$.

Table 4: Effect of temperature on biomass and total protein fraction of Pseudomonas aeruginosa (MTCC 2453)

\begin{tabular}{lcl}
\hline S. No. & Temperature in ${ }^{\circ} \mathbf{C}$ & Total protein content $(\mathbf{m g} / \mathbf{m l})$ \\
\hline 1 & 30 & $2.14 \pm 0.06$ \\
2 & 35 & $2.35 \pm 0.05$ \\
3 & 37 & $2.69 \pm 0.05$ \\
4 & 40 & $2.09 \pm 0.03$ \\
5 & 45 & $1.18 \pm 0.02$ \\
6 & 50 & $1.04 \pm 0.04$ \\
\hline
\end{tabular}

Data represent as mean \pm standard error (SE) for three replicates $(n=3)$.

Table 5: Effect of Incubation time on biomass and total protein fraction of Pseudomonas aeruginosa (MTCC 2453)

\begin{tabular}{lcl}
\hline S. No & Incubation time (h) & Total protein content(mg/ml) \\
\hline 1 & 12 & $4.28 \pm 0.05$ \\
2 & 24 & $3.54 \pm 0.06$ \\
3 & 48 & $3.84 \pm 0.05$ \\
4 & 72 & $3.23 \pm 0.06$ \\
\hline
\end{tabular}

Data represent as mean \pm standard error (SE) for three replicates $(n=3)$.

\section{DISCUSSION}

Bacteria and its proteins show selectivity for tumor tissues. Bacteria and their spores also serve as ideal vectors for delivering therapeutic proteins to tumors [13]. Peptides from Pseudomonas aeruginosa PAO1 leads to Apoptosis in Human Cancer Cell Lines. In this work, it was proposed to increase the biomass and protein content of Pseudomonas aeruginosa $[15,16]$.

Pseudomonas aeruginosa (MTCC no 2453) was cultivated LuriaBertani (LB) broth, minimal medium9 (M9), and asparagine-proline (AP) $[17,18]$. Asparagine proline broth allows high growth rate as it contains a strictly mineral base with asparagine as a sole source of nitrogen and glycerol as the carbon source. The potassium salts act as a buffer system and magnesium sulfate is a source of magnesium ion required in a large variety of enzymatic reactions, including DNA replication and acts as a buffer. $\mathrm{NaHCO}_{3}$ and copper sulfate in optimized asparagine-proline broth increased the yield of biomass and protein content of the cell extract. Initially, shake flask culture was developed. Asparagine proline broth medium achieved higher cell density, of about $2.42 \mathrm{~g} / \mathrm{l}$ dry cell weight. Optimized asparagineproline broth supplemented with copper sulfate increased the biomass to $4.34 \mathrm{~g} / \mathrm{l}$. Super broth produced final cell densities of 1.98 $\mathrm{g} / \mathrm{l}$ dry cell weight, respectively. LB medium also did not support growth due to higher concentrations of yeast extract, and sodium chloride, in the 5X LB medium. M9 medium was less effective as it lacks in carbon/nitrogen.

Extracellular soluble protein in culture was estimated by the Lowry's method using bovine serum albumin (BSA) used as a standard. Temperature affects bacterial biomass production [19]. As there is an increase in temperature, there was an increase in yield of the total protein content till $37^{\circ} \mathrm{C}$. Biomass growth was optimum till $48 \mathrm{~h}$ of incubation. A decrease or increase in the incubation temperature leads to the lower growth of the organism.

The $\mathrm{pH}$ value of culture medium affects the biosynthesis of metabolites [20]. The earlier studies revealed that an optimum $\mathrm{pH}$ range for the growth of bacterial strains is between 6.0 and 7.0[21]. In case of Pseudomonas high biomass and protein content was observed at slightly alkaline $\mathrm{pH}$. Incubation period effected the growth of the culture. Longer incubation period reduced the total protein content of the culture. It may be due to the accumulation of other by-products in the medium [22].

\section{CONCLUSION}

Pseudomonas aeruginosa contains genes encoding anti-cancer proteins. In this work, various media and cultural conditions were evaluated to increase biomass and total protein content of Pseudomonas aeruginosa MTCC 2453. The biomass was high when the organism grown in optimized asparagine-proline broth. The total protein content was more at $37^{\circ} \mathrm{C}$, at a slightly alkaline $\mathrm{pH}$. Hence, Pseudomonas aeruginosa MTCC 2453 can be selected as a potential producer of anticancer proteins which could find applications in the pharma industry. Further studies need to be carried out to commercialize the production and purification process of anti-cancer proteins.

\section{CONFLICTS OF INTERESTS}

All authors have none to declare

\section{REFERENCES}

1. Bernardes N, Seruca R, Chakrabarty AM, Fialho AM. Microbialbased therapy of cancer: current progress and future prospects. Bioengineered Bug 2010;1:178-90.

2. Fialho AM, Bernardes N, Chakrabarty AM. Recent patents on live bacteria and their products as potential anticancer agents. Recent Pat Anti-Cancer Drug Discovery 2012;7:31-55.

3. Bernardes N, Chakrabarty AM, Fialho AM. Engineering of bacterial strains and their products for cancer therapy. Appl Microbiol Biotechnol 2013;97:5189-99.

4. Almas Okassov, Armen Nersesyan, Sakae Kitada, Alexander Ilin. Parasporins as new natural anticancer agents: a review. J BUON 2015;20:5-16.

5. Michio ohba, Eiichi mizuki, Akiko uemori. Parasporin, a new anticancer protein group from Bacillus thuringiensis. Anticancer Res 2009;29:427-34.

6. Baron C, Ocallaghan D, Lanka E. Bacterial secrets of secretion. Mol Microbiol 2002;43:1359-65.

7. Llosa M, Gomis-Ruth FX, Coll M, de la Cruz F. Bacterial conjugation: a two-step mechanism for DNA transport. Mol Microbiol 2002;45:1-8.

8. Puri RK. Development of a recombinant interleukin 4 Pseudomonas exotoxin for therapy of glioblastoma. Toxicol Pathol 1999;27:53-7.

9. Tomasz M Karpiński, Anna K Szkaradkiewicz. Anticancer peptides from bacteria. Bangladesh J Pharmacol 2013;8:343-8.

10. Charlotte F Michelsen, Helle Jensen, Vincent J Venditto, Rosanna C Hennessy. Peter stougaard bioactivities by a crude extract from 
the greenlandic Pseudomonas sp. In5 involves the nonribosomal peptides, nunamycin, and nunapeptin. Peer J 2015;3:e1476.

11. Stover KC, Pham XQ, Erwin AL, Mizoguchi SD, Warrener $P$ Hickey MJ, et al. Complete genome sequence of Pseudomonas aeruginosa PA01: an opportunistic pathogen. Nature 2000; 406:959-64.

12. Ding Z, Peng L, Chen Y, Zhang L, Gu Z, Shi G, et al. Production and characterization of thermostable laccase from the mushroom, Ganoderma lucidum using submerged fermentation. Afr J Microbiol Res 2012;6:1147-57.

13. Shah AH, Kamboh AA, Rajput N, Korejo NA. Optimization of physicochemical conditions for the growth of Pasteurella multocida under in vitro. J Agric Soc Sci 2008;4:176-9.

14. Khusro A, Sankari D. Synthesis and estimation of total extracellular protein content in Bacillus subtilis under mild stress condition of certain antimicrobials. Asian J Pharm Clin Res 2014;8:88-90.

15. Patyar S, Joshi R, Prasad Byrav DS, Prakash A, Medhi B, Das BK. Bacteria in cancer therapy: a novel experimental strategy. J Biomed Sci 2010;17:21.

16. Dolores Vazquez-Rivera, Omar Gonzalez, Jaquelina GuzmanRodriguez, Alma L Dlaz-Perez, Ochoa-Zarzosa, Jose LopezBucio, et al. Cytotoxicity of cyclodipeptides from Pseudomonas aeruginosa PA01 leads to apoptosis in human cancer cell lines. Biomed Res Int 2015. http://dx.doi.org/10.1155/2015/ 197608.

17. Swati Jain, Ponmariappan S, Richa Sijoria, Goel AK, Om Kumar, Lokendra Singh. Optimization of a simple method for the high- yield production of recombinant bont/b light chain protein in E. coli hetero locus host system. J Biotechnol Lett 2012;3:20-7.

18. Elsayed MA, Hassan MM, Elshafei AM, Haroun BM, Othman AM. Optimization of cultural and nutritional parameters for the production of laccase by Pleurotus ostreatus ARC280. $\mathrm{Br}$ Biotechnol J 2012;2:115-32.

19. Praveesh BV, Soniyamby AR, Mariappan C, Kavithakumari P, Palaniswamy M. Production of biosurfactant using cashew nut shell liquid as the carbon source from Pseudomonas aeruginosa MTCC 424. Global J Biotechnol Biochem 2010;5:216-9.

20. Kim HO, Lim JM, Joo JH, Kim SW, Hwang HJ, Choi JW, et al. Optimization of submerged culture condition for the production of mycelial biomass and exopolysaccharides by Agrocybe cylindracea. Bioresour Technol 2005;96:1175-82.

21. Gupta R, Gigras P, Mohapatra H, Goswami VK, Chauhan B. Microbial $\alpha$-amylases: a biotechnological prospective. Process Biochem 2003;38:1599-616.

22. Promita D, Saimon Ahmad T, Kaniz M, Palash Kumar S, Abu Sayem SM. Production and partial characterization of extracellular amylase enzyme from Bacillus amyloliquefaciens P-001. SpringerPlus 2013;2:154.

\section{How to cite this article}

- $\quad$ P Neeraja, T Parthasarathy, M Sudhakar. Evaluation of different culture media for enhanced production of Pseudomonas aeruginosa (MTCC NO 2453) biomass and its proteins. Int J Pharm Pharm Sci 2016;8(11):120-123. 